\title{
Differential Pulse Anodic Stripping Voltammetric Determination of Selenium (IV) in Bulk and in Dosage Formulations Using a Gold Electrode Modified with a Mixture of o-Phenylenediamine and 2,3- Diaminonapthhalene-Nafion
}

\author{
Abdul Aziz Ramadan ${ }^{1 *}$, Hasna Mandil ${ }^{2}$, Abdulrahman Shikh-Debes ${ }^{3}$ \\ Department of Chemistry, Faculty of Science, University of Aleppo, Syria. \\ dramadan@scs-net.org, ${ }^{2}$ promandil955@gmail.com, ${ }^{3} \mathrm{Abd} . s h . d @$ hotmail.com
}

\begin{abstract}
The effect of gold electrode modified with 2,3-Diaminonaphthalene $\left(G E M_{D A N} N\right)$ or multi-modified or a mixture 2,3-diaminonaphthalene and o-phenylenediamine -nafion (GEM DAN-OPDA $_{\text {N }}$ ) on determination of selenium (IV) using differential pulse anodic stripping voltammetric analysis (DPASVA) has been studied. Various parameters (electrolyte, deposition time, pulse duration, pulse amplitude, etc.) are affecting determination of the Se (IV) in $\mathrm{HClO}_{4}(0.2 \mathrm{M})$ at $\mathrm{pH} 0.22$ were examined. Under the optimum conditions, calibration graph, $\mathrm{I}_{\mathrm{p}}=\mathrm{f}\left(\mathrm{C}_{\text {See }(\mathrm{IV})}\right)$, were obtained in the concentration ranges of $5 \times 10^{-8}-1 \times 10^{-6} \mathrm{M}\left(3.948-78.96 \mathrm{ng} \cdot \mathrm{mL}^{-1}\right)$ with relative standard deviations (RSD) $\leq 4.2 \%$ and detection limit $0.056 \mathrm{ng} \cdot \mathrm{mL}^{-1}$, and $1 \times 10^{-9}-1 \times 10^{-6} \mathrm{M}\left(0.07896-78.96 \mathrm{ng} \cdot \mathrm{mL}^{-1}\right)$ with relative standard deviations $(R S D) \leq 4.9 \%$ and detection limit was 0.014 ng. $\mathrm{mL}^{-1}$ on $\mathrm{GEM}_{\text {DAN N }}$ and $\mathrm{GEM}_{\text {DAN }}$ ${ }_{O P D A} \mathrm{~N}$, respectively. This method showed a good accumulation efficiency for selenium and good resistance to interferences from metal ions as well as those associated with selenium in pharmaceuticals. The results for the determination of Se (IV) using GEM $_{\text {DAN-OPDA }} \mathrm{N}$ (multi-modified) were more sensitive (about 50 times) than that obtained using $\mathrm{GEM}_{\mathrm{DAN}} \mathrm{N}$.
\end{abstract}

Keywords: Multi-modified, 2,3-Diaminonaphthalene, o-Phenylenediamine, Nafion, Selenium (IV), Differential pulse anodic stripping voltammetry.

Date of Submission: 2018-09-30

Date of Acceptance: 2018-10-25

Date of Publication: 2018-10-31

DOI 10.24297/jac.v15i2.7560

ISSN: 2321-807X

Volume: 15 Issue: 02

Journal: Journal of Advances in Chemistry

Website: https://cirworld.com

This work is licensed under a Creative Commons Attribution 4.0 International License.

\section{INTRODUCTION}

The performance of a poly (1,8-diaminonaphthalene)-modified gold electrode (PDAN-Au) for the determination of the selenium (IV) ion in an aqueous medium was investigated with anodic stripping voltammetry without the pretreating of the sample. The detection limit employing the anodic stripping differential pulse voltammetry was $9.0 \times 10^{-9} \mathrm{M}$ for Se (IV) with $4.4 \%$ of RSD [1]. 
Differential pulse cathodic stripping voltammetric determination of selenium from pharmaceutical products was applied. The peak potential is $-0.545 \mathrm{~V}\left(\mathrm{vs} . \mathrm{Ag} / \mathrm{AgCl}\right.$ ), and the calibration curve is linear up to $0.125 \mathrm{ng} \cdot \mathrm{mL}^{-}$ ${ }^{1}$, but selenium was determined in the range 8 to $64 \mathrm{ng} \cdot \mathrm{mL}^{-1}$ in pharmaceutical products [2].

Electropolymerization of 3,3'-diaminobenzidine on a gold surface gave an adherent, stable film of poly(3,3'diaminobenzidine) (PDAB). This polymer film retained the complexational functionalities of its monomer, demonstrating preconcentration abilities for several ions, including Se (IV) and Te(IV). In particular, in this work, continuous flow and flow injection methods were developed for the sensitive and selective determination of Te (IV). The optimized method for the continuous flow mode had a detection limit of $5.6 \times 10^{-9} \mathrm{M}$ for $10 \mathrm{~min}$ preconcentration [3].

Determination of Se (IV) was investigated on 3,3'-diaminobenzidine/nafion/ mercury film modified glass carbon electrode (DNMFE). The 3,3'-diaminobenzidine/ nafion coating solution was irradiated by a tungsten light bulb to oxidize the 3,3'-diaminobenzidine. This coating solution was then spin-coated onto glass carbon electrode. Mercury was electrodeposited onto the electrode surface. Se (IV) was preconcentrated onto the DNMFE from the sample solution staturated with EDTA at an accumulation potential of $-0.350 \mathrm{~V}$, and determined by cathodic square-wave stripping voltammetry (SWSV). The analytical signal was linear from 1 to $300 \mu \mathrm{g} \cdot \mathrm{L}^{-1}$ with $5 \mathrm{~min}$ accumulation [4].

Differential pulse anodic stripping voltammetric analysis of selenium (IV) using a gold electrode modified with 3,3'-diaminobenzidine.4HCl-nafion (GEMDN) has been studied. Selenium (IV) was determined. Liner calibration graph was obtained in the concentration ranges of $5 \times 10^{-9} \mathrm{M}$ to $2 \times 10^{-6} \mathrm{M}$ with $\mathrm{RSD} \leq 4.6 \%$ [5].

DPASVA of selenium (IV) using a gold electrode modified with o-Phenylenediamine-nafion has been studied. Liner calibration graph, $\mathrm{I}_{\mathrm{p}}=\mathrm{f}\left(\mathrm{C}_{\mathrm{Se}^{4+}}\right)$, was obtained in the concentration ranges of 3.948 to $78.96 \mathrm{ng} \cdot \mathrm{mL}^{-1}$ with relative standard deviations (RSD) $\leq 3.8 \%$, and the detection limit was $0.048 \mathrm{ng} \cdot \mathrm{mL}^{-1}[6]$.

Differential pulse anodic stripping voltammetric determination of selenium (IV) using a vitamin E-nafion modified gold electrode has been studied. Selenium (IV) was determined. Liner calibration graph was obtained in the concentration ranges of $5 \times 10^{-8}-1 \times 10^{-5} \mathrm{M}$ with relative standard deviations (RSD) $4.5 \%$ [7].

A simple, direct and very sensitive DPASVA of selenium (IV) in bulk and in dosage formulations using a gold electrode multi-modified with a mixture of $\left\{3,3^{\prime}\right.$-diaminobenzidine. $4 \mathrm{HCl}$ and vitamin $E\left(\mathrm{~V}_{\mathrm{E}}\right)$-nafion $\}\left(\mathrm{GEMDV}_{\mathrm{E}} \mathrm{N}\right)$ has been studied. Liner calibration graph was obtained in the concentration ranges of $1 \times 10^{-9}-1 \times 10^{-6} \mathrm{M}$ with relative standard deviations (RSD) $4.8 \%$ [8].

Many spectrophotometric methods for the determination of selenium have been reported with some chromogenic reagents, such as 3,3-diaminobenzidine tetrahydrochloride], 2,3-diaminonaphthalene, 2mercapto benzothiazole, o-phenylenediamine], dithizone], 8-hydroxyquinoline, leuco crystal violet, variamine blue], methylene blue, and iodide [9-12].

Atomic absorption spectrometry methods for the determination of selenium with continuous-flow hydride generation electrothermal atomic absorption spectrometry with in situ trapping on an iridium-coated graphite tube has been chosen because of the high sensitivity and relative simplicity [13-16].

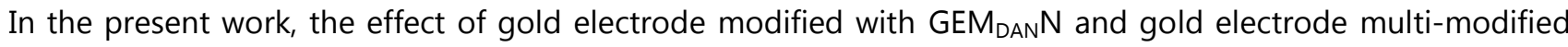
with a mixture o-phenylenediamine and 2,3-diaminonaphthalene-nafion on determination of selenium (IV) using differential pulse anodic stripping voltammetric analysis has been studied. 


\section{EXPERIMENTAL}

\subsection{Reagents}

Nafion perfluorinated ion-exchange resin in ethanol $(3 \%, v / v)$ was purchased from Aldrich. OPhenylenediamine, mol. mass $108.144 \mathrm{~g} / \mathrm{mol}$ (Scheme 1) were of analytical grade from Merck. 2,3Diaminonaphthalene, molecular weight $158.2 \mathrm{~g} / \mathrm{mol}$ (Scheme 2) was from Aldrich. $\mathrm{H}_{2} \mathrm{SeO}_{3}$ and all other reagents were of analytical grade from Merck.

Scheme 1: O-Phenylenediamine, $\left(\mathrm{C}_{6} \mathrm{H}_{8} \mathrm{~N}_{2}\right)$ or O-PDA<smiles>Nc1ccccc1N</smiles>

Scheme 2: 2,3-Diaminonaphthalene, $\left(\mathrm{C}_{10} \mathrm{H}_{10} \mathrm{~N}_{2}\right)$ or DAN<smiles>Nc1cc2ccccc2cc1N</smiles>

\subsection{Apparatus}

A polarograghic analyzer, model PRG-5 (Tacussel), with increasing amplitude pulses was used

for differential detection of current and for superimposing constant amplitude pulses of negative or positive polarity and pulses of linearly increasing amplitude as the source of scanning voltage. A programmer model POLARMAX-78, and a recorder model ECOSRIPT (Tacussel) were also used. A rotating disk gold electrode (RDGE) model DI-65-14 was used as a working electrode. The reference electrode was $\mathrm{Ag} / \mathrm{AgCl}$ model BJC. The solution was stirred with a rotating electrode and was kept in a thermostat at $25^{\circ} \mathrm{C}$. The diluter pipette model DIP-1 (Shimadzu), having $100 \mu \mathrm{L}$ sample syringe and five continuously adjustable pipettes covering a volume range from 5 to $5000 \mu \mathrm{L}$ (model PIPTMAN P, GILSON), were used for preparation of the experimental solutions.

\subsection{Preparation of $\mathrm{HClO}_{4}$ solution}

$\mathrm{HClO}_{4}$ solution $0.20 \mathrm{M}$ at $\mathrm{pH}=0.22$ was prepared from $\mathrm{HClO}_{4}(70 \%)$. The concentration of $\mathrm{HClO}_{4}$ was determined using a standard solution of $\mathrm{NaOH}$.

\subsection{Preparation of stock solutions (a) and (b) of Se (IV)}

Stock solutions of Se (IV) $0.01 \mathrm{M}$, i.e. $789.6 \mu \mathrm{g} \cdot \mathrm{mL}^{-1}$ (a) and $0.1 \mathrm{mM}$, i.e. $7.896 \mu \mathrm{g} \cdot \mathrm{mL}^{-1}$ (b) were prepared from $\mathrm{H}_{2} \mathrm{SeO}_{3}$ using $\mathrm{HClO}_{4}$ solution. The concentration of Se (IV) was determined using reference method [2]. All working solutions for voltammetric investigations were prepared by dilution of the stock solutions of Se (IV) (a or b) with $\mathrm{HClO}_{4}$ solution.

\subsection{Preparation of modified gold electrode $\left(\mathrm{GEM}_{\mathrm{DAN}} \mathrm{N}\right)$}

Gold electrode was first polished, rinsed with deionized water and ultrasonicated successively in a 1:1 aqueous solution of nitric acid and an ethanol solution for $3 \mathrm{~min}$ and then dried. A modified solution was prepared by putting $4.5 \mathrm{~mL}$ of DAN $\left(0.8 \mathrm{mg} \cdot \mathrm{mL}^{-1}\right)$ and $3 \mathrm{~mL}$ of nafion-ethanol solution $(10 \% \mathrm{v} / \mathrm{v})$ in $10 \mathrm{~mL}$ volumetric flask, then the volume was diluted to the mark with ethanol (this solution contents $0.36 \mathrm{mg}^{\mathrm{mL}}{ }^{-1}$ DAN and $3 \% \mathrm{v} / \mathrm{v}$ 
nafion). A modified gold electrode was prepared by placing $5 \mu \mathrm{L}$ from modified solution onto the dry electrode with a micro syringe. The electrode was dried to evaporate the solvent and rinsed with deionized water $\left(G E M_{D A N} N\right)$.

\subsection{Preparation of multi-modified gold electrode (GEM DAN-OPDA )}

Gold electrode was first polished, rinsed with deionized water and ultrasonicated successively in a 1:1 aqueous solution of nitric acid and an ethanol solution each for $3 \mathrm{~min}$ and then dried. A modified solution was prepared by putting $0.25 \mathrm{~mL}$ of DAN $\left(0.8 \mathrm{mg}^{\mathrm{mL}}{ }^{-1}\right), 4.75 \mathrm{~mL}$ of OPDA $\left(10 \mathrm{mg} \cdot \mathrm{mL}^{-1}\right)$, and $3 \mathrm{~mL}$ of nafion-ethanol solution $(10 \% \mathrm{v} / \mathrm{v})$ in $10 \mathrm{~mL}$ volumetric flask, then the volume was diluted to the mark with ethanol (this solution contents $0.02 \mathrm{mg} \cdot \mathrm{mL}^{-1}$ DAN, $4.75 \mathrm{mg} \cdot \mathrm{mL}^{-1}$ OPDA and $3 \% \mathrm{v} / \mathrm{v}$ nafion). A multi-modified gold electrode was prepared by placing $5 \mu \mathrm{L}$ modified solution onto the dry electrode with a micro syringe. The electrode was dried to evaporate the solvent and rinsed with deionized water (GEMDAN-OPDAN).

\subsection{Sample preparation}

A commercial formulation (as tablet) were used for the analysis of Se (IV) by using DPASVA with GEM DANN or GEM DAN-OPDAN. The pharmaceutical formulations were subjected to the analytical procedures:

(1) DaVita Silver Plus tablets, Ultra Medica, Sydnaya-SYRIA, each tablet contains: $70 \mu g$ Selenium.

(2) Daily-Vit tablets, Biomed, Damascus-SYRIA, each tablet contains: $70 \mu \mathrm{g}$ Selenium.

(3) Adult Vit Silver tablets, Aphamea, Hama-SYRIA, each tablet contains: $25 \mu \mathrm{g}$ Selenium.

(4) Cenvite tablets, Pharmasyr Co., Damascus - SYRIA, each tablet contains: $25 \mu \mathrm{g}$ Selenium.

(5) Cenvite Silver tablets, Pharmasyr Co., Damascus-SYRIA, each tablet contains: $20 \mu \mathrm{g}$ Selenium.

Three tablets of each studied pharmaceutical formulations were placed in the crucible of platinum, burning it until the flame was ended, then crushed and dissolved with $10 \mathrm{~mL}$ nitric acid (65\%). After that, it was heated until the drought, then dissolved with $\mathrm{HClO}_{4}$ solution and filtered over a $100 \mathrm{~mL}$ flask and diluting to $100 \mathrm{~mL}$ with $\mathrm{HClO}_{4}$ solution. Five stock solutions of pharmaceuticals: DamVita Silver Plus, Daily-Vit, Adult Vit Silver, Cenvite and Cenvite Silver which content: 2100, 2100, 750, 750 and $600 \mathrm{ng}^{\mathrm{mL}} \mathrm{L}^{-1}$ of Se (IV), respectively.

\subsection{Working solutions of pharmaceuticals}

These solutions were prepared by diluting $1.19,1.19,3.33,3.33$ and $4.17 \mathrm{~mL}$ of stock solutions of pharmaceuticals respectively to $100 \mathrm{~mL}$ with $\mathrm{HClO}_{4}$ solution (each one content $25 \mathrm{ng} \cdot \mathrm{mL}^{-1}$ selenium).

\subsection{Working standard additions solutions of pharmaceuticals}

These solutions were prepared as the follows: same mentioned volumes of stock solutions of pharmaceuticals with $0.000,0.100,0.200,0.400$ and $0.600 \mathrm{~mL}$ from stock solution (b) of selenium and diluting to $100 \mathrm{~mL}$ with $\mathrm{HClO}_{4}$ solution; each one content $25 \mathrm{ng} \cdot \mathrm{mL}^{-1}$ selenium (from pharmaceutical formulations) with 7.896, 15.792, 31.584 and $47.376 \mathrm{ng} \cdot \mathrm{mL}^{-1}$ selenium from standard additions solutions of Se (IV), respectively.

\subsection{Procedure}

A $10 \mathrm{~mL}$ volume of a working solution containing an appropriate concentration of Se (IV) was transferred into an electrochemical cell. The accumulation potential $(-350 \mathrm{mV})$ was applied to the modified electrode for a certain time. The potential scanned was from +400 to $+1250 \mathrm{mV}$ by differential pulse anodic stripping voltammetry using the auto-scan facility. The peak height was measured at 995 to $1010 \mathrm{mV}$. 


\section{RESULTS AND DISCUSSION}

\subsection{Voltammetric behavior}

The differential pulse anodic stripping voltammograms using the procedure described above with an electrode modified $G M_{\text {DAN }} N$ or multi-modified GEM DAN-OPDAN show that the sensitivity increased approximately 50 times $\left(\mathrm{C}_{\mathrm{Se}(\mathrm{I})} \geq 1 \times 10^{-9} \mathrm{M}\right)$ by using GEM DAN-OPDA $\mathrm{N}$. While the sensitivity by using $\mathrm{GEM}_{\text {DAN } N}$ or GEMO-PN [6] not reached less than $5 \times 10^{-8} \mathrm{M}$.

\subsection{Effect of $\mathrm{pH}$ solution}

Effect of $\mathrm{pH}$ on differential pulse anodic stripping voltammograms of Se (IV) using GEM DANN or GEM DAN-OPDA $N$ were studied. It was found that the best $\mathrm{pH}$ solution 0.22 .

\subsection{Effect of modified and multi-modified gold electrode composition}

The effect of the nafion and DAN concentrations in modified solution for formation GEM $_{D A N} N$ on the peak current was studied. The peak current reached its maximum when the concentrations of nafion and DAN were $3 \% \mathrm{v} / \mathrm{v}$ and $0.36 \mathrm{mg}^{\mathrm{mL}} \mathrm{L}^{-1}$, respectively.

The effect of the nafion, DAN and OPDA concentrations in multi - modified solution for formation GEM DAN${ }_{\text {OPDAN }} \mathrm{N}$ on the peak current was studied. The peak current reached its maximum when the concentrations of nafion, DAN and OPDA were $3 \% \mathrm{v} / \mathrm{v}, 0.02 \mathrm{mg} \cdot \mathrm{mL}^{-1}$ and $4.75 \mathrm{mg} \cdot \mathrm{mL}^{-1}$, respectively.

\subsection{Effect of the accumulation potential}

The dependence of the differential pulse anodic stripping peak current on the accumulation potential was examined. It was found that the maximum response for selenium (IV) occurs with accumulation potentials equal to $-0.350 \mathrm{~V}$ on $\mathrm{GEM}_{\mathrm{DAN}} \mathrm{N}$ and $\mathrm{GEM}_{\mathrm{DAN}-\mathrm{OPDA}} \mathrm{N}$.

\subsection{Effect of accumulation time}

The peak current increases with increasing accumulation time. The current is nearly linear from 50 to $400 \mathrm{~s}$. The best time was $300 \mathrm{~s}$ for Se (IV) concentrations $5 \times 10^{-8}-1 \times 10^{-6} \mathrm{M}$ on $\mathrm{GEM}_{\mathrm{DAN}} \mathrm{N}$ and $300 \mathrm{~s}$ for Se (IV) concentrations $1 \times 10^{-9}-1 \times 10^{-6} \mathrm{M}$ on $\mathrm{GEM}_{\text {DAN-OPDA }} \mathrm{N}$.

\subsection{Effect of other factors}

The other influencing factors on the peak current were studied, it found that the preferred values are as follows: waiting time, drop modified size, initial potential, final potential, peak potential, scan rate, stirring speed and temperature of solution were $5 \mathrm{~s}, 5 \mu \mathrm{L},+400 \mathrm{mV},+1250 \mathrm{mV}, 995-1010 \mathrm{mV}, 10 \mathrm{mV}, 1000 \mathrm{rpm}$ and $25^{\circ} \pm 0.5^{\circ} \mathrm{C}$, respectively.

Various parameters (electrolyte, accumulation time, accumulation potential, $\mathrm{pH}$ solution, scan rate, waiting time, stirring speed of electrode, initial potential, final potential and composition of modified solution) are affecting the Se (IV) determination were examined. The optimum parameters for DPASV determination of selenium (IV) were selected and presented in the (Table 1).

\section{Analytical results}

The analytical curves, $I_{p}=f\left(C_{\text {Se(IV) }}\right)$ for the determination of Se (IV) in presence of $0.20 \mathrm{M} \mathrm{HClO}_{4}$ on $\mathrm{GEM}_{\text {DAN }} \mathrm{N}$ and GEM DAN-OPDA $\mathrm{N}$ by DPASVA showed linear proportionality over the concentration range from 3.948 to 78.96 ng. $\mathrm{mL}^{-1}\left(5 \times 10^{-8}\right.$ to $\left.1 \times 10^{-6} \mathrm{M}\right)$ of Se (IV) ${ }^{\text {on }} \mathrm{GEM}_{\mathrm{DAN}} \mathrm{N}$ and from 0.07896 to $78.96 \mathrm{ng} \cdot \mathrm{mL}^{-1}\left(1 \times 10^{-9}\right.$ to $\left.1 \times 10^{-6} \mathrm{M}\right)$ of 
Se (IV) on GEM DAN-OPDAN with accumulation (deposition) time $300 \mathrm{~s}$ (Figures 1-3). Regression equations and correlation coefficient were as the follows:

$y=0.2552 x+0.0858\left(R^{2}=0.9997\right)$ for the concentration of Se (IV) from 3.948 to $78.96 \mathrm{ng}^{\mathrm{mL}} \mathrm{L}^{-1}\left(5 \times 10^{-8}\right.$ to $1 \times 10^{-6}$ M) and $y=0.5279 x+0.1836\left(R^{2}=0.9997\right)$ for the concentration of Se (IV) from 0.07896 to $78.96 \mathrm{ng} \cdot \mathrm{mL}^{-1}$ $\left(1 \times 10^{-9}\right.$ to $\left.1 \times 10^{-6} \mathrm{M}\right)$ at $\mathrm{GEM}_{\text {DAN }} \mathrm{N}$ and at GEM $\mathrm{DAN}_{\mathrm{OPDA}} \mathrm{N}$, respectively, In this method it was determined a low concentration of Se (IV) $3.948 \mathrm{ng} \cdot \mathrm{mL}^{-1}\left(5 \times 10^{-8} \mathrm{M}\right)$ with relative standard deviation did not exceed $\pm 4.2 \%$ at $\mathrm{GEM}_{\text {DAN }} \mathrm{N}$ and a very low concentration $0.07896 \mathrm{ng} \cdot \mathrm{mL}^{-1}\left(1 \times 10^{-9} \mathrm{M}\right)$ of Se (IV) with relative standard deviation did not exceed $\pm 4.9 \%$ at GEM DAN-OPDAN (Tables 2 and 3 ). This method showed very sensitive results for the determination of Se (IV) on GEM DAN-OPDA $N$ more than the results obtained by using $\mathrm{GEM}_{\text {DAN }} \mathrm{N}_{\text {or }} \mathrm{GEM}_{\text {OPDA }} \mathrm{N}$ about 50 times. The results are in good agreement with those obtained by the reference method [8].

Table 1: The optimum parameters established for differential pulse anodic stripping voltammetric determination of selenium (IV).

\begin{tabular}{|c|c|c|c|}
\hline \multirow[b]{2}{*}{ Parameters } & \multicolumn{3}{|c|}{ Operating modes } \\
\hline & $\begin{array}{c}\text { O-PDA } \\
\text { (GEM-O-PN) [6]) }\end{array}$ & $\begin{array}{c}\text { DAN } \\
\left(G_{\left.E M_{\text {DAN }} N\right)}\right.\end{array}$ & $\begin{array}{c}\text { Mixture of DAN and } \\
\text { O-PDA (GEM } \\
\text { OPDAN) }\end{array}$ \\
\hline $\begin{array}{c}\text { Accumulation (deposition) } \\
\text { time }\end{array}$ & \multicolumn{3}{|c|}{$300 \mathrm{~s}$} \\
\hline Accumulation potential & \multicolumn{3}{|c|}{$-350 \mathrm{mV}$} \\
\hline Supporting electrolyte & \multicolumn{3}{|c|}{$0.20 \mathrm{M} \mathrm{HClO}_{4}$} \\
\hline Indicator electrode & \multicolumn{3}{|c|}{ Rotating disk gold electrode (RDGE) } \\
\hline pH solution & \multicolumn{3}{|c|}{0.22} \\
\hline $\begin{array}{l}\text { Modified electrode } \\
\text { composition }\end{array}$ & $\begin{array}{l}4.75 \mathrm{mg} \cdot \mathrm{mL}^{-1} \\
\text { O-PDA + 3\% v/v } \\
\text { nafion-ethanol }\end{array}$ & $\begin{array}{c}0.36 \mathrm{mg} \cdot \mathrm{mL}^{-1} \mathrm{DAN} \\
+3 \% \mathrm{v} / \mathrm{v} \text { nafion- } \\
\text { ethanol }\end{array}$ & $\begin{array}{c}0.02 \mathrm{mg} \cdot \mathrm{mL}^{-1} \text { of } \\
\text { DAN }+4.75 \mathrm{mg} / \mathrm{ml} \\
\text { of O-PDA }+3 \% \mathrm{v} / \mathrm{v} \\
\text { nafion-ethanol }\end{array}$ \\
\hline Waiting time & \multicolumn{3}{|c|}{$5 \mathrm{~s}$} \\
\hline Drop modified size & \multicolumn{3}{|c|}{$5 \mu \mathrm{L}$} \\
\hline Initial potential & \multicolumn{3}{|c|}{$+400 \mathrm{mV}$} \\
\hline Final potential & \multicolumn{3}{|c|}{$+1250 \mathrm{mV}$} \\
\hline Peak potential & \multicolumn{3}{|c|}{$995-1010 \mathrm{mV}$} \\
\hline Scan rate & \multicolumn{3}{|c|}{$10 \mathrm{mV} / \mathrm{s}$} \\
\hline Stirring speed & \multicolumn{3}{|c|}{$1000 \mathrm{rpm}$} \\
\hline Temperature of solution & \multicolumn{3}{|c|}{$25^{\circ} \pm 0.5^{\circ} \mathrm{C}$} \\
\hline
\end{tabular}



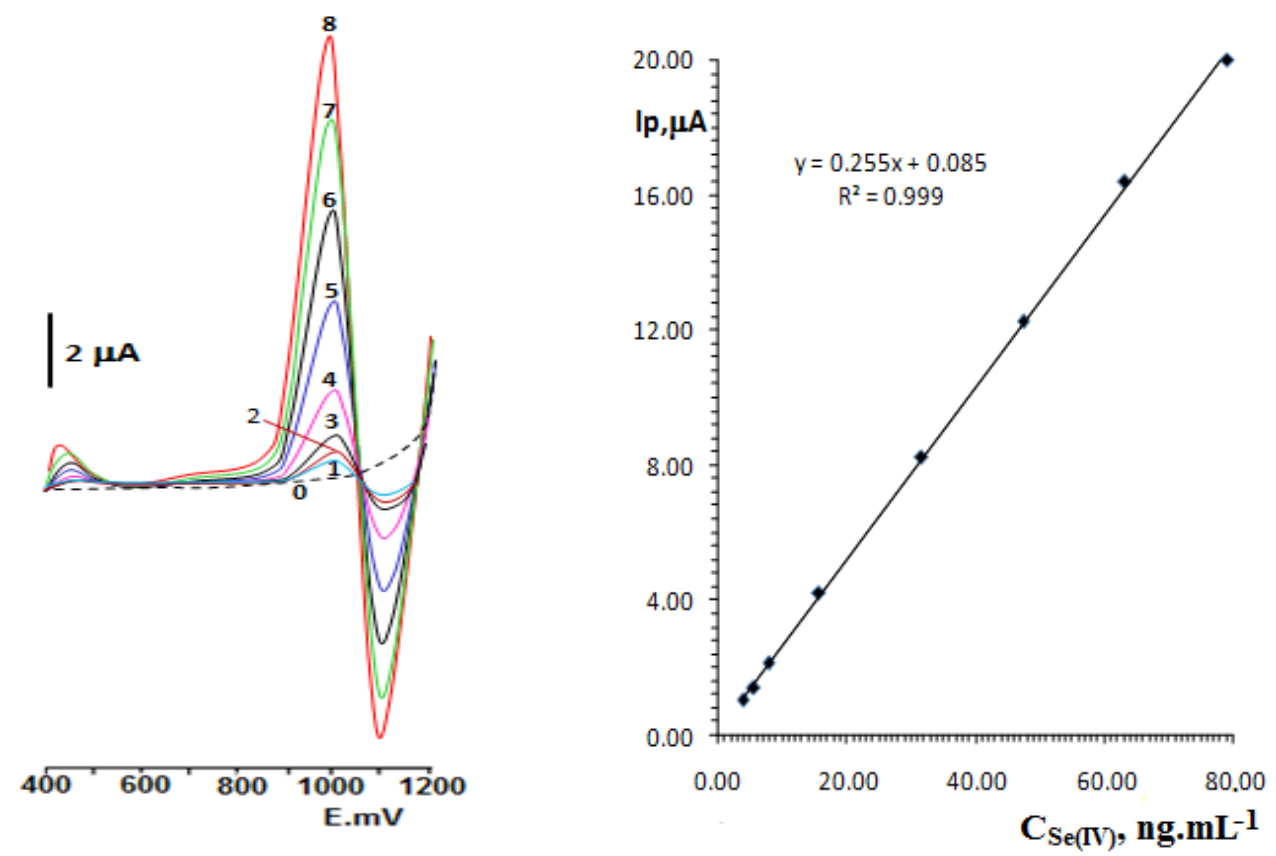

Fig.1. Determination of Se (IV) in presence of $0.20 \mathrm{M} \mathrm{HClO}_{4}$ by DPASVA using $\mathrm{GEM}_{\mathrm{DAN}} \mathrm{N}$. when $\mathrm{C}_{\mathrm{Se}(\mathrm{IV}) \text { : }}$ 0- electrolyte, 1- 3.948, 2- 5.5272, 3- 7.896, 4- 15.792, 5- 31.584, 6- 47.376, 7- 63.168 and 8- 78.96 ng. $\mathrm{mL}^{-1}$. (accumulation time $300 \mathrm{~s}$, accumulation potential $-350 \mathrm{mV}, \mathrm{pH}=0.22$, scan rate $10 \mathrm{mV} / \mathrm{s}$, temperature $25^{\circ} \pm 0.5^{\circ} \mathrm{C}, \mathrm{n}=5$ ).
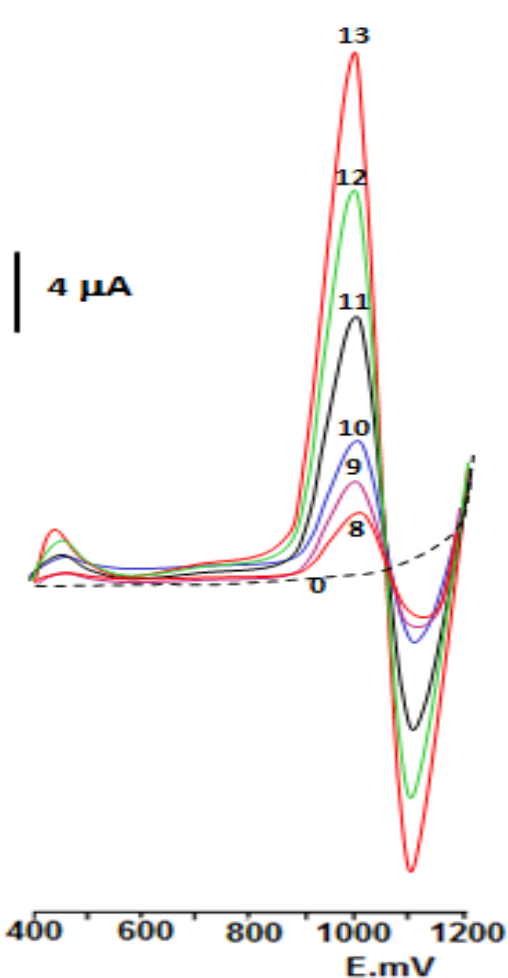
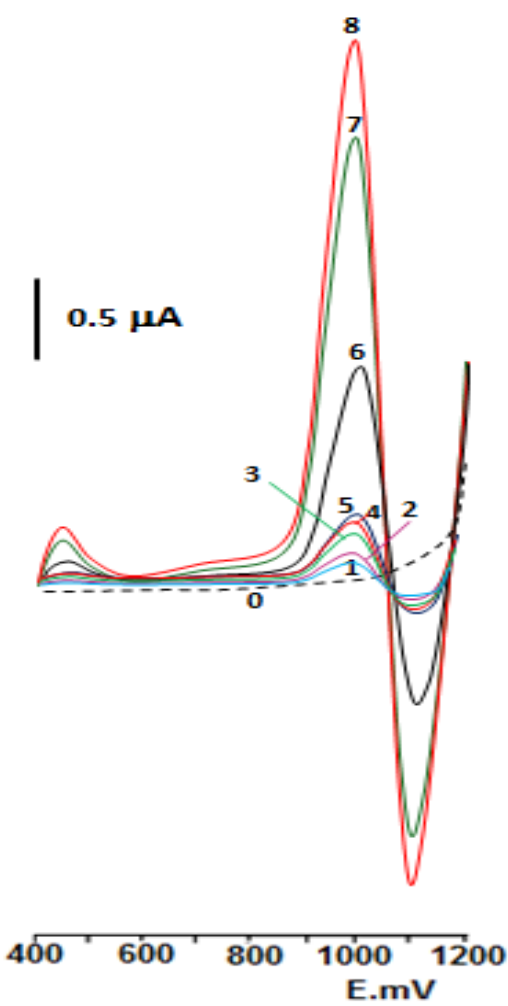

Fig.2. Determination of Se (IV) in presence of $0.20 \mathrm{M} \mathrm{HClO}_{4}$ by DPASVA using GEMDAN-OPDAN when $\mathrm{C}_{\mathrm{Se}}$ 0- electrolyte, 1- 0.07896, 2- 0.15792, 3- 0.47376, 4- 0.63168, 5- 0.7829, 6- 3.948, 7- 7.896, 8- 9.87, $14.805,10-19.74,11-39.48,12-59.22$ and $13-78.96 \mathrm{ng}^{-1} \mathrm{~mL}^{-1}$. (accumulation time $300 \mathrm{~s}$, accumulation potential $-350 \mathrm{mV}, \mathrm{pH}=0.22$, scan rate $10 \mathrm{mV} / \mathrm{s}$, temperature $25^{\circ} \pm 0.5^{\circ} \mathrm{C}, \mathrm{n}=5$ ). 

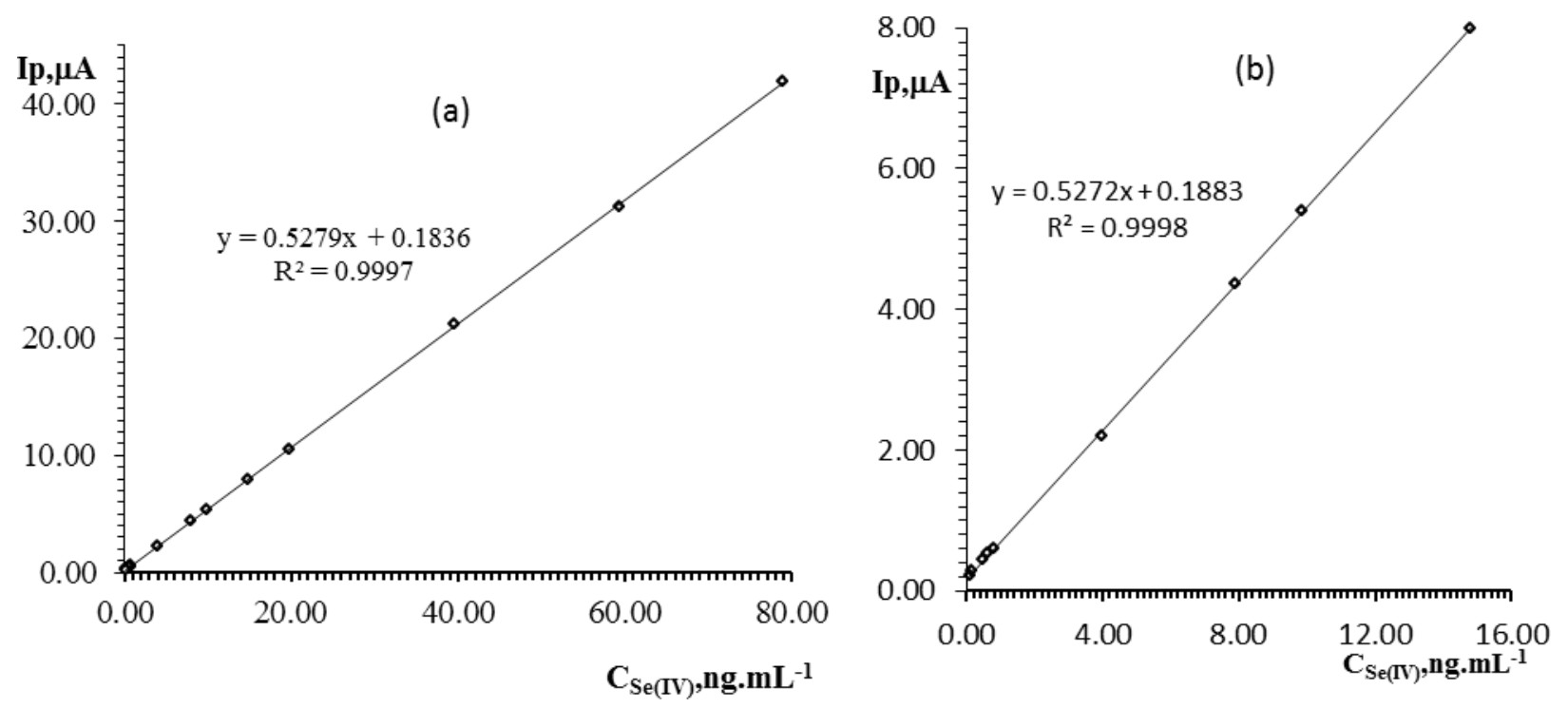

Fig.3. Calibration curves for the determination of Se (IV) using DPASVA on GEM DAN-OPDAN in the optimum conditions. Ip $=f\left(C_{S e(I V)}\right)(a) 0.07896-78.96 n g \cdot \mathrm{mL}^{-1}$, (b) $0.07896-14.805$ ng. $\mathrm{mL}^{-1}$.

Table 2: Determination of selenium (IV) by DPASVA on $\mathrm{GEM}_{\mathrm{DAN}} \mathrm{N}$ for $\mathrm{C}_{\mathrm{Se}(\mathrm{IV})} 3.948$ - $78.960 \mathrm{ng} \cdot \mathrm{mL}^{-1}$; Where (a) using O-PDA [6] and (b) using DAN (accumulation time: $300 \mathrm{~s}$, accumulation potential $-350 \mathrm{mV}, \mathrm{pH}=0.22$, scan rate $10 \mathrm{mV} / \mathrm{s}$, temperature $25^{\circ} \pm 0.5^{\circ} \mathrm{C}, \mathrm{n}=5$ AND $\mathrm{t}=2.776$ ).

\begin{tabular}{|c|c|c|c|c|c|c|}
\hline $\begin{array}{c}\mathrm{x}_{\mathrm{i}}, \mathrm{ng} \cdot \mathrm{mL}^{-1} \\
\text { (taken) }\end{array}$ & $\begin{array}{c}\text { gold } \\
\text { electrode } \\
\text { modified }\end{array}$ & $\begin{array}{c}\bar{x}, \mathrm{ng} \cdot \mathrm{mL}^{-1} \\
\text { (found) }\end{array}$ & $\mathrm{SD}$, & $\frac{S D}{\sqrt{n}}, \mathrm{ng}^{-1} \mathrm{~mL}^{-1}$ & $\bar{x} \pm \frac{t . S D}{\sqrt{n}}, \mathrm{ng} \cdot \mathrm{mL}^{-1}$ & $\mathrm{RSD} \%$ \\
\hline \multirow{2}{*}{3.948} & (a) & 3.820 & 0.145 & 0.0650 & $3.820 \pm 0.180$ & 3.8 \\
\cline { 2 - 7 } & (b) & 3.582 & 0.150 & 0.0673 & $3.582 \pm 0.187$ & 4.2 \\
\hline \multirow{2}{*}{5.5272} & (a) & 5.495 & 0.198 & 0.0885 & $5.495 \pm 0.246$ & 3.6 \\
\cline { 2 - 7 } & (b) & 5.150 & 0.206 & 0.0921 & $5.150 \pm 0.256$ & 4.0 \\
\hline \multirow{2}{*}{7.896} & (a) & 8.112 & 0.284 & 0.127 & $8.112 \pm 0.352$ & 3.5 \\
\cline { 2 - 7 } & (b) & 7.893 & 0.284 & 0.127 & $7.893 \pm 0.352$ & 3.6 \\
\hline \multirow{2}{*}{15.792} & (a) & 16.225 & 0.487 & 0.218 & $16.225 \pm 0.604$ & 3.0 \\
\cline { 2 - 7 } & (b) & 16.121 & 0.532 & 0.238 & $16.121 \pm 0.660$ & 3.3 \\
\hline \multirow{2}{*}{31.584} & (a) & 31.222 & 0.937 & 0.420 & $31.222 \pm 1.163$ & 3.0 \\
\cline { 2 - 7 } & (b) & 31.850 & 0.987 & 0.441 & $31.850 \pm 1.226$ & 3.1 \\
\hline \multirow{2}{*}{47.376} & (a) & 48.092 & 1.298 & 0.580 & $48.092 \pm 1.611$ & 2.7 \\
\cline { 2 - 7 } & (b) & 47.689 & 1.431 & 0.640 & $47.689 \pm 1.776$ & 3.0 \\
\hline \multirow{2}{*}{63.168} & (a) & 62.728 & 1.568 & 0.701 & $62.728 \pm 1.947$ & 2.5 \\
\cline { 2 - 7 } & (b) & 63.927 & 1.598 & 0.715 & $63.927 \pm 1.984$ & 2.5 \\
\hline \multirow{2}{*}{78.960} & (a) & 78.951 & 1.737 & 0.777 & $78.951 \pm 2.156$ & 2.2 \\
\cline { 2 - 7 } & (b) & 78.034 & 1.795 & 0.803 & $78.034 \pm 2.229$ & 2.3 \\
\hline
\end{tabular}


Table 3: Determination of selenium (IV) by DPASVA on GEM DAN-OPDA $\mathrm{N}$ for $\mathrm{C}_{\mathrm{Se}(\mathrm{IV})} 0.07896-0.7896 \mathrm{ng} \cdot \mathrm{mL}^{-1}$ (accumulation time $300 \mathrm{~s}$, accumulation potential $-350 \mathrm{mV}, \mathrm{pH}=0.22$, scan rate $10 \mathrm{mV} / \mathrm{s}$, temperature $25^{\circ} \pm$ $0.5^{\circ} \mathrm{C}, \mathrm{n}=5$ and $\left.\mathrm{t}=2.776\right)$.

\begin{tabular}{|c|c|c|c|c|c|c|c|}
\hline \multirow{2}{*}{$\begin{array}{c}\mathrm{x}_{\mathbf{i}}, \\
\mathrm{ng} \cdot \mathrm{mL}^{-1} \\
\text { (taken) }\end{array}$} & \multirow{2}{*}{$\begin{array}{c}\bar{x} \\
\mathrm{ng} \cdot \mathrm{mL}^{-1} \\
\text { (found) }\end{array}$} & \multirow{2}{*}{$\begin{array}{c}\text { SD, } \\
\text { ng.mL } L^{-1}\end{array}$} & \multirow{2}{*}{$\begin{array}{c}\frac{S D}{\sqrt{n}}, \\
\text { ng.mL }{ }^{-1}\end{array}$} & \multirow{2}{*}{$\begin{array}{l}\bar{x} \pm \frac{t \cdot S D}{\sqrt{n}}, \\
\mathbf{n g} \cdot \mathbf{m L}^{-1}\end{array}$} & \multirow{2}{*}{$\begin{array}{c}\text { RSD } \\
\%\end{array}$} & \multicolumn{2}{|c|}{ found [8] } \\
\hline & & & & & & $\begin{array}{c}\bar{x} \pm \mathrm{SD} \\
\mathrm{ng} \cdot \mathrm{mL}^{-1}\end{array}$ & $\begin{array}{c}\text { RSD } \\
\%\end{array}$ \\
\hline 0.07896 & 0.0722 & 0.00354 & 0.001582 & $0.0722 \pm 0.0044$ & 4.9 & $0.0772 \pm 0.0062$ & 4.8 \\
\hline 0.15792 & 0.1549 & 0.00744 & 0.00333 & $0.1549 \pm 0.0033$ & 4.8 & $0.1552 \pm 0.0073$ & 4.7 \\
\hline 0.47376 & 0.4869 & 0.02191 & 0.00980 & $0.6426 \pm 0.0272$ & 4.5 & $0.4902 \pm 0.023$ & 4.6 \\
\hline 0.63168 & 0.6426 & 0.0283 & 0.0126 & $0.7999 \pm 0.035$ & 4.4 & $0.6486 \pm 0.029$ & 4.5 \\
\hline 0.78290 & 0.7999 & 0.0320 & 0.0143 & $0.7999 \pm 0.040$ & 4.0 & $0.7705 \pm 0.034$ & 4.4 \\
\hline 3.948 & 3.816 & 0.1450 & 0.0649 & $3.816 \pm 0.180$ & 3.8 & $3.902 \pm 0.153$ & 3.9 \\
\hline 7.896 & 7.913 & 0.2849 & 0.1274 & $7.913 \pm 0.354$ & 3.6 & $7.836 \pm 0.290$ & 3.7 \\
\hline 9.870 & 9.886 & 0.3446 & 0.1547 & $9.886 \pm 0.430$ & 3.5 & $9.845 \pm 0.364$ & 3.7 \\
\hline 14.805 & 14.817 & 0.5038 & 0.2253 & $14.817 \pm 0.625$ & 3.4 & $14.860 \pm 0.550$ & 3.7 \\
\hline 19.740 & 19.542 & 0.6449 & 0.2884 & $19.542 \pm 0.800$ & 3.3 & $19.660 \pm 0.727$ & 3.7 \\
\hline 39.480 & 39.933 & 1.3178 & 0.5894 & $39.933 \pm 1.636$ & 3.3 & $40.718 \pm 1.470$ & 3.6 \\
\hline 59.220 & 58.754 & 1.9389 & 0.8671 & $58.754 \pm 2.407$ & 3.3 & $58.984 \pm 2.064$ & 3.5 \\
\hline 78.960 & 79.122 & 2.5319 & 1.1323 & $79.122 \pm 3.143$ & 3.2 & $78.478 \pm 2.750$ & 3.5 \\
\hline
\end{tabular}

\section{APPLICATIONS}

Many applications for the determination of Se (IV) in some pharmaceutical preparations by DPASVA on GEMDAN -OPDAN $_{\text {N }}$ using the optimum parameters were proposed. Standard addition curves for determination of Se (IV) in different pharmaceutical preparations (DamVita Silver Plus, Daily-Vit, Adult Vit Silver, Cenvite and Cenvite Silver) were used. Regression equations and correlation coefficients were included in (Table 4). Standard additions on curves for determination of Se (IV) in different pharmaceutical preparations were used. The amount $(\mathrm{m})$ of Se (IV) in one tablet by $\mu \mathrm{g} / \mathrm{tab}$ calculated from the following relationship: $\mathrm{m}=\mathrm{h} . \mathrm{m}$ ', where: $\mathrm{m}^{\prime}$ is the amount of Se (IV) in tablet, which calculated from the standard additions curve according to the following regression equation: $y=a \cdot x+b$; when $y=0 ; m^{\prime}=x=b / a=\operatorname{intercept} /$ slope $\left(n g \cdot \mathrm{mL}^{-1}\right)$ and $h$ conversion factor is equal to 2.8, 2.8, 1.0, 1.0 and 0.8 for all pharmaceuticals content 70, 70, 25, 25 and 20 $\mu \mathrm{g} / \mathrm{tab}$, respectively. The results of quantitative analysis for Se (IV) in the pharmaceutical preparations using this method included in (Table 5). The proposed method was simple, economic, accurate and successfully applied to the determination of Se (IV) in pharmaceuticals. The results obtained agree well with the contents stated on the labels. 
Table 4: Regression equations and correlation coefficients for determination of $\mathrm{C}_{\mathrm{Se}(\mathrm{V})}$ in pharmaceutical preparations using DPASV on GEM DAN-OPDAN (accumulation time $300 \mathrm{~s}$, accumulation potential $-350 \mathrm{mV}$, $\mathrm{pH}=0.22$, scan rate $10 \mathrm{mV} / \mathrm{s}$, temperature $25^{\circ} \pm 0.5^{\circ} \mathrm{C}$ and $\mathrm{n}=5$ ).

\begin{tabular}{|c|c|c|c|c|c|}
\hline \multirow{2}{*}{$\begin{array}{c}\text { Pharmaceutical } \\
\text { preparations }\end{array}$} & \multirow{2}{*}{$\begin{array}{c}\mathrm{C}_{\mathrm{Se}(\mathrm{IV})} \\
\text { in tab., } \\
\mu \mathrm{g}\end{array}$} & \multicolumn{4}{|c|}{ Operating modes } \\
\hline & & $\begin{array}{l}{ }^{*} \text { Regression } \\
\text { equations }\end{array}$ & $\begin{array}{c}\text { Correlation } \\
\text { coefficients }\end{array}$ & $\begin{array}{c}\mathbf{m} \mathbf{n}^{\prime} \\
\mathbf{n g} \cdot \mathrm{mL}^{-1}\end{array}$ & $\begin{array}{c}\text { Amount of Se }{ }^{4+} \\
(\mathrm{m}), \mu \mathrm{g} / \mathrm{tab}\end{array}$ \\
\hline $\begin{array}{l}\text { DamVita Silver Plus } \\
\text { tablets, Ultra Medica, } \\
\text { Sydnaya-SYRIA }\end{array}$ & 70 & $\begin{array}{c}y=0.5278 x+ \\
13.459\end{array}$ & $R^{2}=0.9988$ & 25.50 & $\mathrm{~m}=2.8 \mathrm{~m}^{\prime}=71.40$ \\
\hline $\begin{array}{l}\text { Daily-Vit tablets, } \\
\text { Biomed, Damascus- } \\
\text { SYRIA }\end{array}$ & 70 & $\begin{array}{c}y=0.5275 x+ \\
13.599\end{array}$ & $R^{2}=0.9990$ & 25.78 & $\mathrm{~m}=2.8 \mathrm{~m}^{\prime}=72.18$ \\
\hline $\begin{array}{l}\text { Adult Vit Silver tablets, } \\
\text { Aphamea, Hama-SYRIA }\end{array}$ & 25 & $\begin{array}{c}y=0.5276 x+ \\
13.063\end{array}$ & $R^{2}=0.9998$ & 24.76 & $\begin{array}{c}\mathrm{m}=1.0 \mathrm{~m}^{\prime}= \\
24.76\end{array}$ \\
\hline $\begin{array}{l}\text { Cenvite tablets, } \\
\text { Pharmasyr Co., Damascus } \\
\text { - SYRIA }\end{array}$ & 25 & $\begin{array}{c}y=0.5270 x+ \\
13.175\end{array}$ & $R^{2}=0.9996$ & 25.00 & $\mathrm{~m}=1.0 \mathrm{~m}^{\prime}=25.00$ \\
\hline $\begin{array}{c}\text { Cenvite Silver tablets, } \\
\text { Pharmasyr Co., } \\
\text { Damascus-SYRIA }\end{array}$ & 20 & $\begin{array}{c}y=0.5273 x+ \\
13.472\end{array}$ & $R^{2}=0.9993$ & 25.55 & $\mathrm{~m}=0.8 \mathrm{~m}^{\prime}=20.44$ \\
\hline
\end{tabular}

Table 5: Determination of Se (IV) in pharmaceutical preparations using DPASV on GEM DAN-OPDAN (accumulation time $300 \mathrm{~s}$, accumulation potential $-350 \mathrm{mV}, \mathrm{pH}=0.22$, scan rate $10 \mathrm{mV} / \mathrm{s}$, temperature $25^{\circ} \pm 0.5^{\circ} \mathrm{C}$ and $\mathrm{n}=5$ ).

\begin{tabular}{|c|c|c|c|c|}
\hline Commercial name & Contents, $\boldsymbol{\mu g}$ /tab. & $\bar{x}, \boldsymbol{\mu g} / \mathbf{t a b}$. & RSD\% & Assay \% \\
\hline $\begin{array}{c}\text { DamVita Silver Plus } \\
\text { tablets, Ultra Medica, } \\
\text { Sydnaya-SYRIA }\end{array}$ & 70 & 71.40 & 2.8 & 102.00 \\
\hline $\begin{array}{c}\text { Daily-Vit tablets, Biomed, } \\
\text { Damascus-SYRIA }\end{array}$ & 70 & 72.18 & 2.6 & 103.11 \\
\hline $\begin{array}{c}\text { Adult Vit Silver tablets, } \\
\text { Aphamea, Hama-SYRIA }\end{array}$ & 25 & 24.76 & 3.2 & 99.04 \\
\hline $\begin{array}{c}\text { Cenvite tablets, Pharmasyr } \\
\text { Co., Damascus - SYRIA }\end{array}$ & 25 & 25.00 & 3.0 & 100.00 \\
\hline $\begin{array}{c}\text { Cenvite Silver tablets, } \\
\text { Pharmasyr Co., Damascus- } \\
\text { SYRIA }\end{array}$ & 20 & 3.4 & 102.20 \\
\hline
\end{tabular}




\section{Validation of Proposed Method}

The developed method for simultaneous estimation of Se (IV) has been validated in accordance with the International Conference on Harmonization guidelines (ICH) [17].

\subsection{Selectivity}

Selectivity test determines the effect of excipients on the assay result. To determine the selectivity of the method, standard solution of Se (IV), commercial product solution and blank solutions were analyzed. The results of the tests proved that the effect of the presence of common excipients no interference.

\subsection{Linearity}

In the proposed methods, linear plots $(n=5)$ with good correlation coefficients were obtained in the concentration ranges of $y=0.2552 x+0.0858\left(R^{2}=0.9997\right)$ on $G^{-1} M_{D A N} N$ for the concentration from 3.948 to $78.96 \mathrm{ng} \cdot \mathrm{mL}^{-1}$ and $y=0.5279 x+0.1836\left(R^{2}=0.9997\right)$ for the concentration from 0.07896 to $78.96 \mathrm{ng} \cdot \mathrm{mL}^{-1}$, respectively, on GEMDAN OPDA $_{\text {N }}$. In this method a very low concentration $0.07896 \mathrm{ng} \cdot \mathrm{mL}^{-1}\left(1 \times 10^{-9} \mathrm{M}\right)$ of Se (IV) on $\mathrm{GEM}_{\mathrm{DAN}-\mathrm{OPDA}} \mathrm{N}$ was determined.

\subsection{Precision and Accuracy}

The precision and accuracy of proposed method was checked by recovery study by addition of standard Se (IV) solution to pre-analyzed sample solution at three different concentration levels $(80 \%, 100 \%$ and $120 \%)$ within the range of linearity for Se (IV). The basic concentration level of sample solution selected for spiking of the Se (IV) standard solution was $14.805 \mathrm{ng} \cdot \mathrm{mL}^{-1}$. The proposed method was validated statistically and through recovery studies. It was successfully applied for the determination of Se (IV) in pure and dosage forms with percent recoveries ranged from $99.3 \%$ to $100.8 \%$ (Table 6).

Table 6: Results of recovery studies $(n=5)$.

\begin{tabular}{|c|c|}
\hline Level & \% Recovery \\
\hline $80 \%$ & 99.3 \\
$100 \%$ & 100.5 \\
$120 \%$ & 100.8 \\
\hline
\end{tabular}

\subsection{Repeatability}

The repeatability was evaluated by performing 10 repeat measurements for $3.948 \mathrm{ng} \cdot \mathrm{mL}^{-1}$ of Se (IV) using the studied method under the optimum conditions in two concentration ranges. The found amount of Se (IV) $(\bar{x} \pm \mathrm{SD})$ was $3.936 \pm 0.143 \mathrm{ng} \cdot \mathrm{mL}^{-1}$ and the percentage recovery was found to be $99.70 \pm 3.6$ with RSD of 0.036 . These values indicate that the proposed method has high repeatability for Se (IV) analysis.

\subsection{Sensitivity (LOD and LOQ)}

The limits of detection (LOD) and quantitation (LOQ) were determined using the formula: LOD or LOQ =jSD/b, where $\mathrm{j}=3.3$ for LOD and 10 for LOQ, SD is the standard deviation of the intercept, and $b$ is the slope. The values of LOD and LOQ for Se (IV) are 0.014 and $0.042 \mathrm{ng} \cdot \mathrm{mL}^{-1}$, respectively. 


\subsection{Robustness}

The robustness of the method adopted is demonstrated by the constancy of the current peak $\left(\mathrm{I}_{\mathrm{p}}\right)$ with the deliberated minor change in the experimental parameters such as the change in the concentration of excipients, temperature $\left(25 \pm 5^{\circ} \mathrm{C}\right), \mathrm{pH}(0.22 \pm 0.01)$, accumulation potential $(-350 \pm 5 \mathrm{mV})$ and $\mathrm{C}_{\mathrm{HClO} 4}(0.20 \pm 0.01$ M), (Table 7) indicates the robustness of the proposed method. $I_{p}$ was measured and assay was calculated for five times.

Table 7: Robustness of the proposed DPASVA method.

\begin{tabular}{|c|c|}
\hline \multirow{2}{*}{$\begin{array}{c}\text { Experimental parameter } \\
\text { variation }\end{array}$} & Average recovery (\%) * \\
\hline & $\mathrm{C}_{\mathrm{Se}(\mathrm{IV})}=14.805 \mathrm{ng} \cdot \mathrm{mL}^{-1}$ \\
\hline \multicolumn{2}{|l|}{ Temperature } \\
\hline $15^{\circ} \mathrm{C}$ & 99.7 \\
\hline $25^{\circ} \mathrm{C}$ & 100.1 \\
\hline \multicolumn{2}{|l|}{$\mathrm{pH}$} \\
\hline 0.21 & 100.5 \\
\hline 0.23 & 99.9 \\
\hline \multicolumn{2}{|l|}{ Accumulation potential } \\
\hline$-345 m V$ & 100.0 \\
\hline$-355 m V$ & 100.4 \\
\hline \multicolumn{2}{|l|}{$\mathrm{C}_{\mathrm{HClO}} 4$} \\
\hline $0.19 \mathrm{~mol} / \mathrm{L}$ & 99.8 \\
\hline $0.21 \mathrm{~mol} / \mathrm{L}$ & 100.3 \\
\hline
\end{tabular}

\subsection{Specificity}

The specificity of the method was ascertained by analyzing standard Se (IV) in solution of pharmaceuticals and presence of excipients. There was no interference.

\subsection{THE HOMOGENIZATION OF TABLETS}

The homogenization of tablets in terms of the weight and the amount of drug was studied. We found that the mean weight and amount drug in the tablets were $1.512 \pm 0.012 \mathrm{~g}$ (i.e. $\pm 0.797 \%$ ), $1.516 \pm 0.016 \mathrm{~g}$ (i.e. $\pm 1.055 \%), 1.410 \pm 0.010 \mathrm{~g}$ (i.e. $\pm 0.710 \%), 1.522 \pm 0.022 \mathrm{~g}$ (i.e. $\pm 1.445 \%$ ) and $1.4082 \pm 0.008 \mathrm{~g}$ (i.e. $\pm 0.568 \%$ ) for DamVita Silver Plus, Daily-Vit s, Adult Vit Silver, Cenvite and Cenvite Silver tablets, respectively. While the mean amount drug in the tablets was $71.40 \pm 2.00 \mu$ g (i.e. $\pm 2.8 \%$ ), $72.18 \pm 1.88 \mu$ g (i.e. $\pm 2.6 \%$ ), $24.76 \pm 0.79 \mu \mathrm{g}$ (i.e. $\pm 3.2 \%$ ), $25.00 \pm 0.75 \mu \mathrm{g}$ (i.e. $\pm 3.0 \%$ ) and $20.44 \pm 0.69 \mu \mathrm{g}$ (i.e. $\pm 3.4 \%$ ) for DamVita Silver Plus, Daily-Vit, Adult Vit Silver, Cenvite and Cenvite Silver tablets, respectively; which shows that homogeneity of tablets is good. 


\section{CONCLUSION}

DPASVA of selenium (IV) using $\mathrm{GEM}_{\text {DAN }} \mathrm{N}$ and $\mathrm{GEM}_{\mathrm{DAN}-\mathrm{OPDA}} \mathrm{N}$ with an aqueous $0.2 \mathrm{M} \mathrm{HClO}_{4}$ medium of pH 0.22 according to the optimal conditions were applied. Liner calibration graphs, $I_{p}=f\left(C_{\text {Se(IV) }}\right)$, were obtained in the concentration ranges of $3.948-78.96$ ng. $\mathrm{mL}^{-1}$ with relative standard deviations (RSD) $\leq 4.2 \%$, the detection limit was $0.056 \mathrm{ng} \cdot \mathrm{mL}^{-1}$ on $\mathrm{GEM}_{\mathrm{DAN} N} \mathrm{~N}$ and the concentration ranges of $0.07896-78.96 \mathrm{ng} \cdot \mathrm{mL}^{-1}$ with relative standard deviations (RSD) $\leq 4.9 \%$, the detection limit was $0.014 \mathrm{ng} \cdot \mathrm{mL}^{-1}$ on $G_{\text {DEAN-OPDA }} \mathrm{N}$. This method showed a good accumulation efficiency for selenium and a good resistance to interferences from metal ions as well as those associated with selenium in pharmaceuticals. This method showed very sensitive results for the

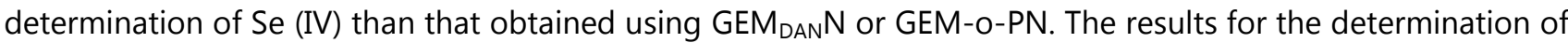
$\mathrm{Se}(\mathrm{IV})$ using $\mathrm{GEM}_{\text {DAN-OPDA }} \mathrm{N}$ were more sensitive and accurate than the results obtained by using $\mathrm{GEM}_{\mathrm{DAN}} \mathrm{N}_{\text {; the }}$ sensitivity was increased about 50 times.

\section{REFERENCES}

1. Mi-Sook, W., Jang-Hee, Y., Yoon-Bo, S., 2005. Determination of Selenium with a poly(1,8-diamino-naphthalene)-modified electrode. Electroanalysis. 17(21):1952-1958.

2. Stoica, A., Babaua, G., Iorgulescu, E., Marinescu, D., Baiulescu, G., 2002. Differrential pulse cathodic stripping voltammetric determination of selenium in pharmaceutical products. J Pharm Biomed Anal. 30(4):1425-1429.

3. Soo, K., Ruidong, Y., 2002. Differential pulse voltammetric determination of trace Te(IV) at a poly(3,3'diaminobenzidine) film modified gold electrode in flow systems. Anal Chim Acta. 453(2):209-220.

4. Hao-Yun, Y., I-Wen, Sun., 2000. Cathodic stripping voltammetric determination selenium(IV) at a nafion coated mercury film electrode modified with 3,3'-diaminobenzidine. Electroanalysis. 12(18):1476-1480.

5. Ramadan, A.A., Mandil, H., Shikh-Debes ,A.A., 2014. Differential pulse anodic stripping voltammetric determination of selenium(IV) at a gold electrode modified with 3,3'-diaminobenzidine.4HCl-Nafion. Int $J$ Pharm Pharm Sci. 6(3):148-153.

6. Ramadan, A.A., Mandil, H., Shikh-Debes ,A.A., 2018.. Differential pulse anodic stripping voltammetric analysis of selenium(IV) at a gold electrode modified with O-phenylenediamine- nafion. J. Pharm. and Tech. 11(5):2030-2035

7. Ramadan, A.A., Mandil, H., Ozoun, A., 2011. Differential pulse anodic stripping voltammetric determination of selenium(IV) with a vitamin E-nafion modified gold electrode. Asian J Chem. 23(2):843-846.

8. Ramadan, A.A., Mandil, H., Shikh-Debes ,A.A., 2017. Development and Validation of differential pulse anodic stripping voltammetric analysis of selenium(IV) in bulk and in dosage formulations at a gold electrode multi-modified with a mixture of 3,3'-diaminobenzidine. $4 \mathrm{HCl}$ and vitamin $\mathrm{E}$. Int J Pharm Pharm Sci. 9(7):97-102.

9. Badiadka, N., Mendalin, M., Nekkarakalaya, G.B. and Naracham, V.S., 2003. Spectrophotometric Determination of Selenium Using Potassium Iodide and Starch as Reagents. Microchim. Acta 141: 175178 .

10. Abdallah A.S., Ivan N.B.C., Bernhard W., Eduardo C., Irland B.G., Martens A.M., Silvia M.F.C., 2011. Method development and optimization for the determination of selenium in bean and soil samples using hydride generation electrothermal atomic absorption spectrometry. Talanta 85(3):1350-1356.

11. Bujdo`s M., Kubov'a Stre`sko J., V., 2000. Problems of selenium fractionation in soils rich in organic 
matter. Analytica Chimica Acta, 408(1-2): 103-109.

12. Vĩnas P., Pardo-Mart'ınez M., ordoba H.M., 2000. Rapid determination of selenium, lead and cadmium in baby food samples using electrothermal atomic absorption spectrometry and slurry atomization. Analytica Chimica Acta. 412(1-2):121-130.

13. Pedro J., Andrade F., Magni D., Tudino M., Bonivardi A., 2004. On-line submicellar enhanced fluorometric determination of Se(IV) with 2,3- diaminonaphthalene. Analytica Chimica Acta. 516(1-2): 229236.

14. Chan C. C. Y., Sadana R. S., 1992. Determination of arsenic and selenium in environmental samples by flowinjection hydride generation atomic absorption spectrometry, Analytica Chimica Acta, 270(1); 231-238.

15. Afkhami A., Safavi A., Massoumi A., 1992. Spectrophotometric determination of trace amounts of selenium with catalytic reduction of bromate by hydrazine in hydrochloric acid media. Talanta, 39( 8): 993996.

16. Ramachandran K. N., Kumar G. S., 1996. Modified spectrophotometric method for the determination of selenium in environmental and mineral mixtures using 2,3- diaminonaphthalene. Talanta, 43(10): 17111714.

17. ICH: Proceedings of the International Conference on Harmonization of Technical Requirement of Registration of Pharmaceuticals for Human Use (ICH Harmonized Tripartite Guidelines)., 2000. 